\title{
Pedological Characterization and Soil Classification of Selected Soil Units of Morogoro District, Tanzania
}

\author{
S. M. Lufega ${ }^{1,2^{\star}}$ and B. M. Msanya ${ }^{1}$ \\ ${ }^{1}$ Department of Soil and Geological Sciences, Sokoine University of Agriculture, P.O.Box 3008, \\ Tanzania. \\ ${ }^{2}$ Department of Water Resource and Irrigation Engineering, Water Institute, P.O.Box 35059,
}

Dar es Salaam, Tanzania.

Authors' contributions

This work was carried out in collaboration between both authors. Author SML designed the study, performed the statistical analysis, wrote the protocol, managed the literature searches and wrote the first draft of the manuscript. Author BMM managed the site selection of the study, edited the data, reviewed and edited the protocol and manuscript. Both authors read and approved the final manuscript.

\section{Article Information}

DOI: $10.9734 /$ IJPSS/2017/32681

Editor(s):

(1) Junhong Bai, School of Environment, Beijing Normal University, Beijing, China. Reviewers:

(1) Carmelo Maria Torre, Polytechnic University of Bari, Italy. (2) El-Sayed Ewis Omran, Suez Canal University, Egypt. Complete Peer review History: http://www.sciencedomain.org/review-history/19020

Original Research Article

Received $9^{\text {th }}$ March 2017 Accepted $22^{\text {nd }}$ April 2017 Published 11 ${ }^{\text {th }}$ May 2017

\begin{abstract}
The study aimed at provision of research information by pedological characterization of soil units of Morogoro District, Tanzania. Three soil units were selected coupled with field reconnaissance survey. Soil pedons were characterized at Kiziwa (KZW-P1), Mkambarani (MKA-P1) and Fulwe (FUL-P1). Pedons were observed to be formed from in-situ weathering of granitic rocks under ustic moisture and iso-hyperthermic temperature regimes. Thirteen soil samples were described and analyzed for physica-chemical and mineralogical properties. KZW-P1 and FUL-P1 had red dark brown sandy clay and gravely clay (MKA-P1) top soils overlaying mainly clayey subsoil. Both pedons indicate clay eluviation-illuviation as a dominant pedogenic process with slightly acidic condition and $\mathrm{P}<7$ except FUL-P1 with $23.8 \mathrm{mg} / \mathrm{kg} \mathrm{P}$ in top soils. Organic carbon is low in both pedons while total $\mathrm{N}$ is low to very low. CEC values for both pedons are $33.8,26.4$ and 27 $\mathrm{cmol}(+) / \mathrm{kg}$ respectively. CIA values indicates intermediate to strong level of weathering. In USDA Soil Taxonomy and the FAO-UNESCO soil classification system, Soils were classified as: Kiziwa
\end{abstract}


Ultisols (Alisols), and Inceptisols (Cambisols) for Fulwe and Mkambarani, reflecting their differences in potentials and constraints and hence use and management. The results reflects variations in soil characteristics both vertically and laterally so as to account for spatial linkages within the landscape.

Keywords: Soil units; soil characterization, soil morphology; physical characteristics; soil classification; Morogoro District Tanzania.

\section{INTRODUCTION}

Soil information obtained through systematic identification, grouping and delineation of various soils present in the locality are important for particular use for effective planning of different land uses, as they provides information related to potentials and constraints of the land. In addition, environmental characteristics (e.g. climate) and socio-economic factors are also important elements in pedological characterization to provides data and knowledge on soil properties related to the site characteristics (slope, soil color, vegetation). According to [1], parent material, biota, relief and time are soil forming factors that influence the morphological, physical, chemical and biological characteristics of soil. Understanding of soil genesis, morphology and other key soil properties is a pre-requisite to sustainable use of soil resources.

At present, soil survey conducted in Morogoro region are normally at large scale, exploratory and and/or reconnaissance scales. For instance, a work by [1] at a scale of 1:1000 000 describes Morogoro region in three physiographic units, the Urugulu mountains, the piedmonts and mountain and ridges which covers very extensive areas classified as Fluvisols, Vertisols and Gleysols. The larger scale of this nature provides limited information at village level in forecasting constraints and limitation of the land. Soil characterization result obtained by researchers in Tanzania [2] give generalization which cannot put into practice at farm level. According to [3], soils vary both in their physical and chemical properties and agricultural production is governed by major soil types and precipitation patterns. Due to the limitation pointed out above, it becomes unavoidable to carry out site specific soil characterization in order to identify the existing heterogeneity of the soil pattern in order to generate required information for purposes of determining the potential of the soils and appropriate soil management practices. Furthermore agronomic technologies developed on such well characterized soils can easily be extrapolated to other areas with similar ecological conditions [2]. A report by other workers [4] is of the same location has pointed out the necessity to carry out site specific soil characterization taking into account as crop production is a function of soil properties. Further to this, site soil resource information is required by agricultural extension staff and farmers as a tool for soil fertility management. Thus, knowledge of site characterized soil physical and chemical properties with other ecological conditions will aid in determining the correct type and amounts of fertilizer to be applied for optimum crop production and nourishment of improved soil fertility.

The current study aimed at on site identification, description and characterization of three soil units of Morogoro District in terms of morphological characteristics, Physico-chemical and mineralogical properties and classification according to the United States Department of Agriculture (USDA) Soil Taxonomy [5] and the FAO-World Reference Base [6].

\section{MATERIALS AND METHODS}

\subsection{Description of the Study Site}

The study was carried out in Morogoro District, Tanzania. Three sites representing three soil units in Morogoro district were identified based on the landforms and physiographic attributes, soil profiles were excavated and described. Soil profiles were located at Kiziwa $06^{\circ} 46^{\prime} 49.6^{\prime \prime} \mathrm{E} /$ $\left.037^{\circ} 51^{\prime} 21.6^{\prime \prime} \mathrm{S}\right)$, Fulwe $\left(06^{\circ} 46^{\prime} 06.9^{\prime \prime}\right.$ "E037 $52^{\prime}$. $\left.31^{\prime \prime} \mathrm{S}\right)$ and Mkambarani $\left(06^{\circ} 46^{\prime} 12.5^{\prime \prime} \mathrm{E} 037^{\circ} 49^{\prime}\right.$ 27.8 " S) at elevation of $417 \mathrm{~m}, 492 \mathrm{~m}$ and $414 \mathrm{~m}$ above sea level respectively. Both pedons are developed from granitic rocks of pre-cambrian age. In terms of physiography, the soils are formed on peneplains with gradients ranging between 2 and $5 \%$. Surface characteristics depicted slight interill/sheet erosion with no deposition in the identified sites.

The climatic condition of the area is characterized by long bimodal rainfall which gets its peak on April-May, while the short rains have 
its peak during December. The maximum temperatures vary between $26.1^{\circ} \mathrm{C}$ to $29.6^{\circ} \mathrm{C}$ and minimum temperature range between $24.5^{\circ} \mathrm{C}$.

\subsection{Field Methods}

A reconnaissance survey was carried out using transect walks, auger observations, and description in the field to identify major landforms and soils. At each observation site, data on landform, elevation, slope, soil morphological characteristics, parent material, vegetation and land use were collected. Three observation land units were selected, In each identified land unit, soil observation was made to a maximum of 1.8 $\mathrm{m}$ or limiting layer. The gathered data were filled to the soil description forms adopted from the FAO guideline for soil description [6]. Three soil profiles were excavated from each soil unit to present the major soil type. Soil profile pits opened were studied, described and sampled according to the FAO guideline [6]. Sites were Geo-referenced by international coordinates using Global Positioning System (GPS) using Global Positioning System (GPS) (model OREGON 400t).

Soil colors were determined by Munsell soil color charts [7]. In each profile pit, undisturbed (core) soil samples at depths of $0-10 / 13 \mathrm{~cm}, 10 / 13-$ $40 / 50 \mathrm{~cm}$, and 90-95/132 cm FUL-P1, 0-20/32 $\mathrm{cm}, 32-65 / 75 \mathrm{~cm}$ and $75-100 / 117 \mathrm{~cm}$ for MKA-P1 and 0-49/69 cm, 49/69-99 and 99-132 cm for KZW-P1 were sampled, while disturbed samples were taken from all designated natural horizons for laboratory physical and chemical analysis.

\subsection{Laboratory Method}

Undisturbed (core ring) samples were used for determination of bulk density, porosity and moisture retention characteristics. Bulk density was determined by the core method [8]. Disturbed soil samples were air-dried, ground and passed through a 2-mm sieve for physical and chemical soil properties. Particle size distribution was determined by hydrometer method [9] after dispersing soil with sodium hexametaphosphate and textural classes determined using the USDA textural triangle [10]. Soil $\mathrm{pH}$ in water was measured potentiometrically using a soil water ratio of 1:2.5 weights to volume basis [11]. Potentiometric method was used to determine electrical conductivity while available phosphorus was extracted using Bray-1 extraction method [12] and determined by spectroscopy at $884 \mathrm{~nm}$ following colour development by the Molybdenum blue method [13]. Organic carbon was determined by WalkeyBlack wet oxidation method [14] and total nitrogen was determined by micro-Kjeldahl digestion method [15].

Cation exchange capacity of the soil $\left(\mathrm{CEC}_{\text {soil }}\right)$ and exchangeable bases were determined by saturating soil with neutral $1 \mathrm{M} \quad \mathrm{NH} 4 \mathrm{OAc}$ (ammonium acetate) and the adsorbed $\mathrm{NH} 4+$ were displaced by using $1 \mathrm{M} \mathrm{KCl}$ and then determined by Kjeldahl distillation method for estimation of CEC of the soil [14]. The exchangeable bases $\left(\mathrm{Ca}^{2+,} \mathrm{Mg}^{2+}, \mathrm{Na}^{+}\right.$and $\left.\mathrm{K}^{+}\right)$ were determined by atomic absorption spectrophotometer [15]. The total exchangeable bases (TEB) were calculated arithmetically as a sum of the four exchangeable bases $\left(\mathrm{Ca}^{2+}, \mathrm{Mg}^{2+}\right.$, $\mathrm{K}^{+}$and $\mathrm{Na}^{+}$) for a given soil sample. Other parameters which were calculated include $\mathrm{C} / \mathrm{N}$ ratio, and base saturation percentage (BS \%). Chemical index of alteration was calculated as a ratio of $\mathrm{Al}_{2} \mathrm{O}_{3} /\left(\mathrm{AL}_{2} \mathrm{O}_{3}+\mathrm{CaO}+\mathrm{Na}_{2} \mathrm{O}+\mathrm{K}_{2} \mathrm{O}\right)$ as described by [16].

\subsection{Soil Classification}

Soil morphological, physical and chemical properties define the diagnostic horizons and other features that assist to classify the soils up to the family level of the Soil Taxonomy [4] and up to Tier-2 category of the FAO World Reference Base [6].

\section{RESULTS AND DISCUSSION}

\subsection{Morphological Characteristics}

Key morphological characteristics of studied soil units are presented on Table 1. Soil horizons were, easily demarcated, ranging from clear to abrupt with either wavy or smooth horizon topography. MKA-P1 and KZW-P1 was very deep, well drained pedons with red dark brown sandy clay top soils overlying dark reddish brown to red clayey sub soils. Abundant distinct clay cutans were observed in the subsoil indicating eluviation-illuviation as dominant pedogenic process. FUL-P1 pedon was deep, well drained with brown sandy loam overlying a sandy loam sub soil. A and B horizons of KZW-P1, FUL-P1 and MKA-P1, had well developed soil structures breaking into moderate to coarse sub-angular blocks. The subsoil of profile FUL-P1 was massive and crumby. 
Table 1. Morphological characteristics of studied soil profiles

\begin{tabular}{|c|c|c|c|c|c|c|c|c|}
\hline Profile no. & Horizon & Depth (cm) & Texture & Dry color & Moist color & Consistence & Structure & Horizon boundary \\
\hline \multirow[t]{4}{*}{ KIZ-P1 } & Ap \# & $0-49 / 60$ & SC & drb (5YR3/2) & $\mathrm{rb}(7.5 \mathrm{YR} 3 / 2)$ & $\mathrm{SHA}, \mathrm{fr}, \mathrm{sm} \& \mathrm{p}$ & $m, f-c$ sbk, $m, m, c r$ & $\mathrm{c} / \mathrm{w}$ \\
\hline & Bt1 & $49 / 60-99$ & C & drb (2.5YR3/4) & $\mathrm{db}(7.5 \mathrm{YR}(3 / 2)$ & $\mathrm{SHA}, \mathrm{HA}, \mathrm{fr}, \mathrm{sp}$ & $w-m, f+m, s b k$ & ds \\
\hline & Bt2 & 99- 132 & C & $\mathrm{dr}(10 \mathrm{YR} 3 / 6)$ & rb (7.5YR2.5/2) & SHA,fr, st \& p & $w-m, f+m, s b k$ & Ds \\
\hline & $\mathrm{Bt3}$ & $132-184$ & C & $r(10 R 4 / 6)$ & $\mathrm{dr}(7.5 \mathrm{YR} 2.5 / 2)$ & SHA, fr, st \& p & $m, m+f, s b k$ & $g-d / s$ \\
\hline \multirow[t]{5}{*}{ FUL-P1 } & Ap & $0-10 / 13$ & SC & b (7.5YR4/4) & $\mathrm{db}(7.5 \mathrm{YR} 3 / 3)$ & SHA,fm, , sm \& p & $\mathrm{m}, \mathrm{m}, \mathrm{sbk}, \mathrm{m}, \mathrm{m}, \mathrm{cr}$ & $\mathrm{c} / \mathrm{s}$ \\
\hline & $A h$ & $13-40 / 50$ & SL & $\operatorname{lbg}(10 Y 6 / 2)$ & $\mathrm{db}(7.5 \mathrm{YR} 3 / 2)$ & SHA,fr,sm\&p & $\mathrm{co}, \mathrm{m}-\mathrm{c}$ wsb & $c / d$ \\
\hline & Bwt1 & $50-95 / 102$ & SCL & $\operatorname{lbg}(10 Y R 6 / 2)$ & rb(7.5YR2.5/2) & VHA, ns \& np & $\mathrm{co}, \mathrm{m}-\mathrm{c}$ wsb & Gw \\
\hline & Bwt2 & $102-129 / 134$ & SCL & dg (10YR5/2) & $\mathrm{dg}(10 \mathrm{YR} 4 / 1)$ & VHA,ns \& np & $\mathrm{co}, \mathrm{m}-\mathrm{c}$ wsb & Gw \\
\hline & $\mathrm{CB}$ & $134-160$ & SL & dg (10YR4/1) & dg (10YR4/1) & VHA,ns \& np & $c o, m-c$ wsb & Gw \\
\hline \multirow[t]{3}{*}{ MKAP1 } & Ap & $0-20 / 32$ & $\mathrm{gC}$ & b(10YR4/2) & $\mathrm{dr}(10 \mathrm{YR} 3 / 1)$ & $H A, f i, s s \& s p$ & $w-m, f+m, c r$ & Gw \\
\hline & Bwt1 & $32-65 / 75$ & $\mathrm{C}$ & $\mathrm{Rb}(5 \mathrm{YR} 5 / 2)$ & $\mathrm{db}(7.5 \mathrm{YR}(3 / 2)$ & Ha,ss \& sp & $m, m+f, s b k$ & Cw \\
\hline & Bwt2 & $65 / 75-100 / 117$ & $\mathrm{gC}$ & rb (10YR4/4) & $\mathrm{lb}(10 \mathrm{YR} 6 / 2)$ & vfr, ss \& sp & Massive,w-m, sbk & $\mathrm{c} / \mathrm{s}$ \\
\hline
\end{tabular}

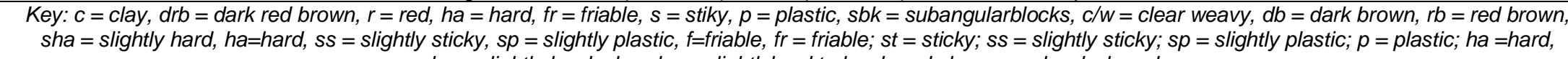
sha = slightly hard, sha - ha = slightlyhard to hard, and vha = very hard when dry
}

$m, f$-c sbk = moderate to coarse subangular blocky; $m, m, c r=$ moderate medium crumby; $w-m, f+m$, sbk = weak to moderate fine and medium subangular blocky;

$m, m, s b k \& a b=$ moderate, medium subangular \& angular blocky; $w-m, s b k=$ massive breaking to weak medium subangular blocky;co, $m-c$ wsb = compact medium to coarse wedge-shaped blocks $a=$ abrupt; $c=$ clear; $g=$ gradual; $s m=$ smooth; $w=$ wavy; $g w$ = gradual wavy; ds = diffuse smooth; aw = abrupt wavy; $c w=c l e a r$ wavy; dw = diffuse wavyp is always italicized and capitalized 


\subsection{Soil Physical Characteristics}

\subsubsection{Soil particle size distribution}

Textural data and textural classes of the studied pedons are presented in Table 2. The Table describes particle size distribution in relation to depth. Particle size distribution for top soils of the studied profiles varied from Sandy clay (KZW-P1), sandy loam (FUL-P1), and sandy clay for MKA-P1. This supports the fact that the three pedons have developed largely under same soil forming factors and have attained comparable degree of pedogenesis [16]. Despite Sandy clay (KZW-P1), and sandy clay for MKA-P1, the two pedons are dominantly clayey type. Silt/clay ratios particularly for subsoils of the two pedons are very low, indicating high level of weathering in this pedons.

\subsubsection{Bulk density and soil moisture characteristic curves}

The determined bulk density for top soils were $1.3,1.5,1.2 \mathrm{~g} / \mathrm{cm}^{3}$ for KZW-P1, FUL-P1 and MKA-P1 respectively (Table 2). Critical levels of bulk densities for clay are 1.0 to $1.6 \mathrm{~g} / \mathrm{cm}^{3}$ and for sand is 1.2 to $1.8 \mathrm{~g} / \mathrm{m}^{3}$ with potential root restriction occurring at $\geq 1.4 \mathrm{~g} / \mathrm{cm}^{3}$ for clay; and $\geq 1.6 \mathrm{~g} / \mathrm{cm}^{3}$ for sand [3]. Pedon FUL-P1 had relatively high bulk density $\left(1.5 \mathrm{~cm}^{3}\right)$ with one unit less to the upper boundary of the critical value. Bulk density guide to rate soil compaction, porosity, root penetration and soil aeration [12] Bulk density determines the magnitude of particle-to-particle contacts and is related to total porosity and has an influence on available soil moisture [17]. The relatively high bulk density value in topsoil may likely reduce water infiltration and favor surface water run-off while an increase of the same with depth could result to poor root growth, reduced aeration and decreased water infiltration. According to [18] bulk density is influenced by the amounts of organic matter in the soil.

The soil moisture of KZW-P1 and MKA-P1 (Fig. 1) indicates a higher retention capacity with a gradual decrease as the suction potential increases. FUL-P1 profile portrays a drastic decrease in available water content as the suction potential increases. These suggests an effect of drastic dryness of field crops whenever there is a dry spell during the rainy season consequently causing plants to experience temporal wilting [18]. The trend of the curves agrees with the seemingly rapid run-off and rapid infiltration under natural drainage as observed in FUL-P1 profile during the field study. Soil moisture characteristic curve (Fig. 1) depends on soil particle size distribution and organic matter content which play an important role especially in low suctions [19].

Table 2. Physical properties of soil units of agricultural soils Morogoro district

\begin{tabular}{|c|c|c|c|c|c|c|c|}
\hline \multirow[t]{2}{*}{ Profile no } & \multirow[t]{2}{*}{ Horizon } & \multirow{2}{*}{$\begin{array}{l}\text { Depth } \\
\text { (cm) }\end{array}$} & \multicolumn{3}{|c|}{$\begin{array}{c}\text { Particle size distribution } \\
(\%)\end{array}$} & \multirow{2}{*}{$\begin{array}{l}\text { Textural } \\
\text { Class }^{\star}\end{array}$} & \multirow{2}{*}{$\begin{array}{l}\begin{array}{l}\text { Bulk } \\
\text { density }\end{array} \\
\mathrm{g} \mathrm{cm}^{-3}\end{array}$} \\
\hline & & & Sand & Silt & Clay & & \\
\hline \multirow[t]{4}{*}{$\mathrm{KZW}-\mathrm{P} 1$} & $A p$ & $0-49 / 60$ & 43.7 & 7.6 & 48.7 & $\mathrm{C}$ & 1.3 \\
\hline & Bt1 & $49 / 60-99$ & 45.7 & 7.6 & 46.7 & SC & 1.4 \\
\hline & $\mathrm{Bt} 2$ & $99-132$ & 47.7 & 13.6 & 38.7 & SC & 1.6 \\
\hline & $\mathrm{Bt3}$ & $117-124$ & 37.7 & 7.6 & 54.7 & $\mathrm{C}$ & n.d \\
\hline \multirow[t]{3}{*}{ MKA_1 } & Ap & $0-20 / 32$ & 45.7 & 3.6 & 50.7 & SC & 1.2 \\
\hline & Bwt1 & $32-65 / 75$ & 37.7 & 9.6 & 52.7 & C & 1.3 \\
\hline & Bwt2 & $65 / 75-100 / 117$ & 51.7 & 5.6 & 42.7 & $\mathrm{SC}$ & 1.2 \\
\hline \multirow[t]{6}{*}{ FUL-P1 } & Ap & $0-10 / 13$ & 77.7 & 9.6 & 31.7 & $S L$ & 1.5 \\
\hline & $\mathrm{Ah}$ & $13-40 / 50$ & 77.7 & 3.6 & 31.7 & SL & 1.5 \\
\hline & Bwt1 & $50-95 / 102$ & 71.7 & 3.6 & 25.7 & SCL & 1.5 \\
\hline & Bwt2 & $102-129 / 134$ & 71.7 & 3.6 & 25.7 & SCL & n.d \\
\hline & $\mathrm{CB}$ & 134-175 & 77.7 & 3.6 & 31.7 & S L & n.d \\
\hline & $\mathrm{C}$ & $175+$ & 83.7 & 5.6 & 37.7 & $\mathrm{~S}$ & n.d \\
\hline
\end{tabular}

Key: $C=$ Clay, $S C=$ Sand Clay, $S L=$ Sandy Loam, SCL = Sandy Clay Loam, n.d= Not Determined 


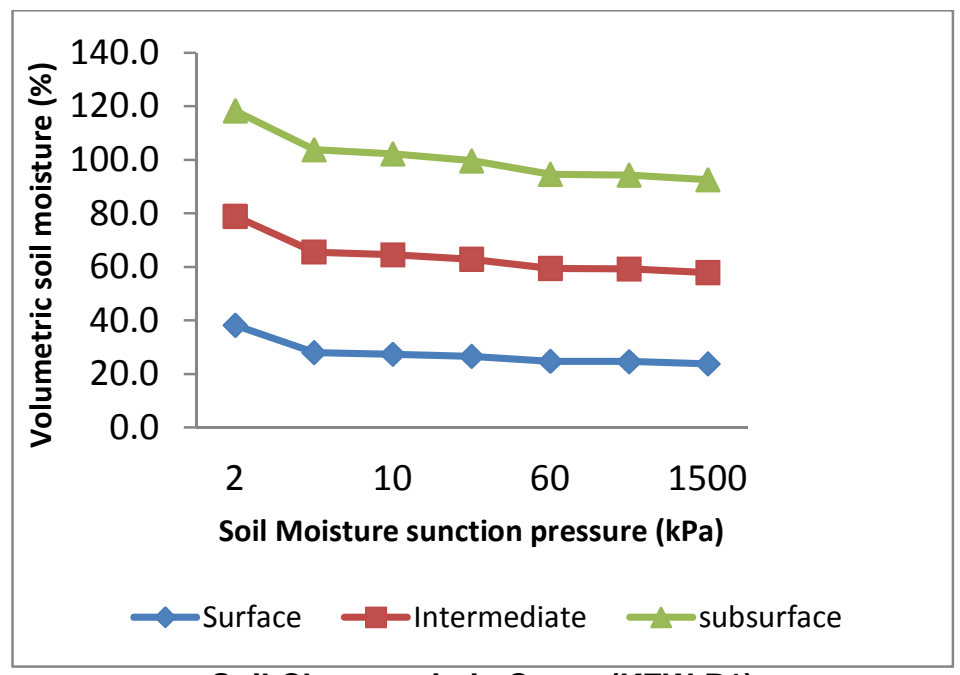

Soil Characteristic Curve (KZW-P1)

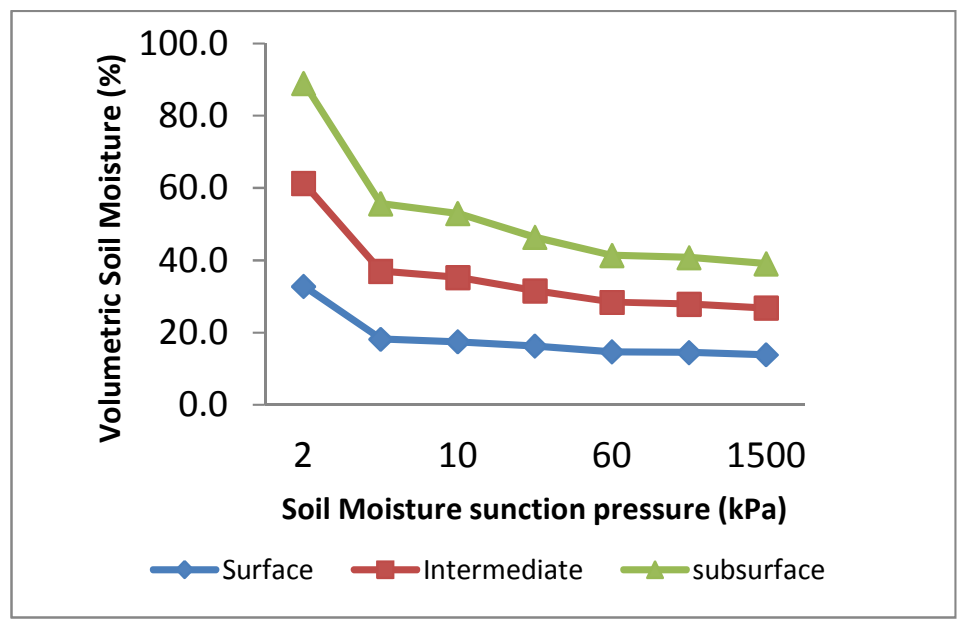

Soil Characteristic Curve (FUL-P1)

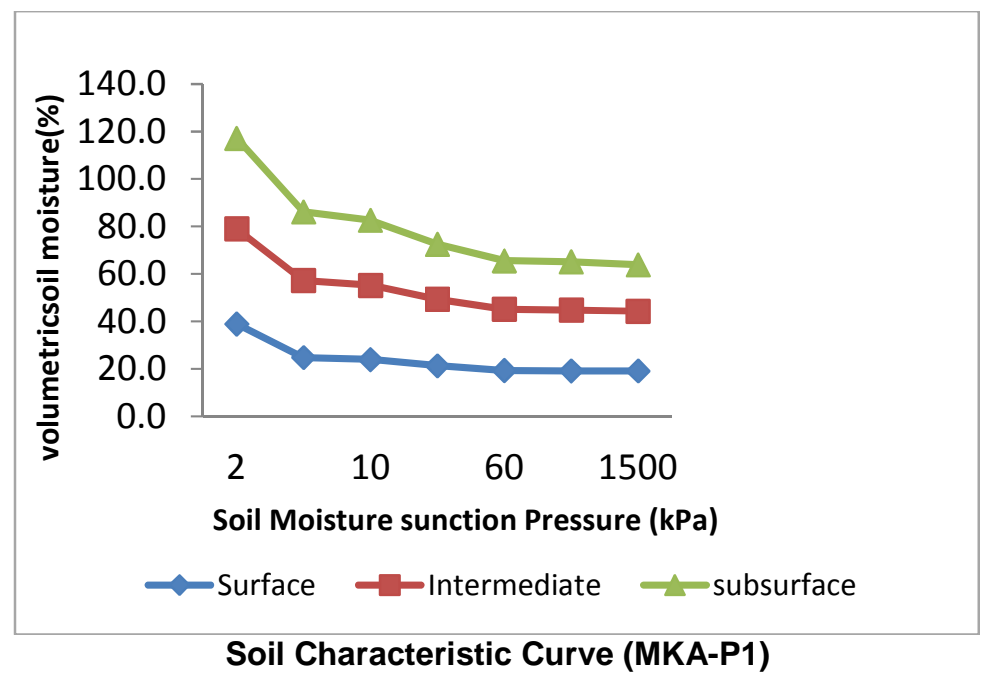

Fig. 1. Soil moisture characteristic curves for the studied soils 


\subsection{Chemical Properties}

Some selected soil characteristics are presented in the Table 3.

\subsubsection{Soil reaction $(\mathrm{pH})$}

According to $[14,20]$ both pedon have slightly acidic condition. The results proves that there no limited nutrients imbalances, toxicity and nutrients unavailability because the $\mathrm{pH}$ is at optimal range of about 6.5 to 7.5 . Low soil $\mathrm{pH}$ values below $\mathrm{pH}<5.5$ have potential to cause toxicity problems and deficiency of some essential plants nutrients as well as affect soil microbial activities [21]. Soil $\mathrm{pH}<5.5$ could also cause dissolution of aluminum and iron minerals which precipitates with phosphorus effectively causing its fixation and further lowering the soil $\mathrm{pH}[22]$.

\subsubsection{Available phosphorus (P)}

According to $[23,12,24]$, both pedons have very low to low $P$ (Below <7), and further below further below the critical level of $2 \mathrm{mg} / \mathrm{kg}$ [17]. The low available $P$ in these soils are linked with $P$ is fixation under alkaline and acid condition to form insoluble compounds [25] and low phosphorus parent materials in which soils were developed such as granitic rocks. Phosphorus availability to plants is strongly influenced by soil
$\mathrm{pH}$, and maximized when $\mathrm{pH}$ is between 5.5 and 7.5 [26].

\subsection{Organic carbon, nitrogen and carbon nitrogen ratio}

Both pedons has low to medium organic carbon content, very low to low Nitrogen and $\mathrm{C} / \mathrm{N}$ ratio of 16 to 12.9. Which are below the critical values for rating of good quantity organic matter. This indicates that organic matter are of moderate to poor quality [24,12]. A correlation between organic carbon and total nitrogen is evident and this agrees with other reports e.g. the works of [27] and [10].

\subsubsection{Exchangeable calcium ( $\mathrm{Ca})$, magnesium (Mg), and potassium (K)}

Exchangeable cations laboratory results of the studied soil is given in Table 4 . Both pedons. Exchangeable cations are being rated as high to medium except exchangeable $\mathrm{K}$ is low at $\mathrm{KZW}$ P1 pedon. Levels of Exchangeable cations has direct implications on the cation exchange capacity (CEC), soil $\mathrm{pH}$ and finally plant nutrient imbalances, unavailability and nutrient induced deficiencies. For example, $\mathrm{Mg}$ acts as a phosphorus carrier in plants and therefore, $\mathrm{P}$ uptake is influenced by Exchangeable $\mathrm{Mg}$ [28].

Table 3. Some chemical properties of agricultural soils of three soil units of Morogoro district, Tanzania

\begin{tabular}{|c|c|c|c|c|c|c|c|c|c|}
\hline \multirow[t]{2}{*}{ Profile } & \multirow[t]{2}{*}{ Hor } & \multicolumn{2}{|c|}{ pH } & \multirow[t]{2}{*}{$\mathrm{EC}(\mathrm{mS} / \mathrm{cm})$} & \multirow[t]{2}{*}{ OC (\%) } & \multirow[t]{2}{*}{ N (\%) } & \multirow{2}{*}{$\begin{array}{l}\mathrm{C} / \mathrm{N} \\
\text { ratios }\end{array}$} & \multirow{2}{*}{$\begin{array}{l}\text { OM } \\
\text { (\%) }\end{array}$} & \multirow{2}{*}{$\begin{array}{l}\text { P } \\
\text { Bray1 P } \\
\text { (mg/kg) }\end{array}$} \\
\hline & & $\mathrm{H}_{2} \mathrm{O}$ & $\mathrm{KCl}$ & & & & & & \\
\hline \multirow[t]{4}{*}{ KZW-P1 } & Ap & 6.9 & 5.1 & 0.04 & 1.2 & 0.27 & 4.4 & 2 & 23.8 \\
\hline & $\mathrm{Bt} 1$ & 6.7 & 5.0 & 0.04 & 0.9 & 0.11 & 8.1 & 1.5 & 1.8 \\
\hline & $\mathrm{Bt} 2$ & 6.3 & 4.8 & 0.06 & 0.8 & 0.08 & 10 & 3.1 & 0.8 \\
\hline & $\mathrm{Bt} 3$ & 5.2 & 7.1 & 0.04 & 0.9 & 0.09 & 10 & 1.7 & 1.1 \\
\hline \multirow[t]{6}{*}{ FUL-P1 } & Ap & 6.9 & 5.6 & 0.03 & 1.17 & 0.16 & 7.3 & 2.0 & 6.9 \\
\hline & Ah & 6.4 & 5.7 & 0.02 & 0.23 & 0.14 & 1.6 & 0.4 & 1.9 \\
\hline & Bwt1 & 5.8 & 5.4 & 0.03 & 0.51 & 0.16 & 3.1 & 0.9 & 3.4 \\
\hline & Bw2 & 6.3 & 4.2 & 0.03 & 0.51 & 0.02 & 25 & 0.9 & 7.1 \\
\hline & Bwt3 & 7.1 & 4.6 & 0.03 & 0.16 & 0.01 & 16 & 0.3 & 4.1 \\
\hline & CB & 7.2 & 4.6 & 0.02 & 0.43 & 0.06 & 7.2 & 0.7 & 1.4 \\
\hline \multirow[t]{3}{*}{ MKA-P1 } & Ap & 6.5 & 5.3 & 0.03 & 1.4 & 0.01 & 1.4 & 2.4 & 1.9 \\
\hline & Ah & 6.8 & 5.5 & 0.04 & 0.8 & 0.09 & 8.8 & 1.3 & 0.7 \\
\hline & Bwt1 & 7.1 & 5.2 & 0.04 & 0.3 & 0.05 & 6 & 0.5 & 0.7 \\
\hline
\end{tabular}


Table 4. Exchangeable bases and the related chemical properties

\begin{tabular}{|c|c|c|c|c|c|c|c|c|}
\hline \multirow[t]{2}{*}{ Site } & \multirow[t]{2}{*}{ Horizon } & \multicolumn{4}{|c|}{ Exchangeable bases $(\mathrm{cmol}(+) / \mathrm{kg})$} & TEB & CEC & BS \\
\hline & & $\mathbf{C a}$ & Mg & $\mathrm{K}$ & $\mathrm{Na}$ & \multicolumn{2}{|c|}{ cmol(+)/kg } & (\%) \\
\hline \multirow[t]{4}{*}{ Kiziwa } & Ap & 11.8 & 1.98 & 0.25 & 0.30 & 14.3 & 33.8 & 42.4 \\
\hline & Bt1 & 11.43 & 2.01 & 0.31 & 0.23 & 14.0 & 26.4 & 53.0 \\
\hline & Bt2 & 9.7 & 0.99 & 0.61 & 0.19 & 11.5 & 28.2 & 40.7 \\
\hline & Bt3 & 9.3 & 1.54 & 0.27 & 0.36 & 11.5 & 27.6 & 41.6 \\
\hline \multirow{6}{*}{ Fulwe } & Ap & 4.096 & 0.20 & 0.70 & 0.07 & 5.1 & 20.4 & 24.8 \\
\hline & Ah & 4.94 & 0.80 & 0.41 & 0.09 & 6.2 & 25.2 & 24.7 \\
\hline & Bwt1 & 4.51 & 0.73 & 0.13 & 0.14 & 5.5 & 18.2 & 30.3 \\
\hline & Bw2 & 4.52 & 0.59 & 0.16 & 0.23 & 5.5 & 17.6 & 31.2 \\
\hline & Bwt3 & 3.93 & 0.67 & 0.10 & 0.01 & 4.7 & 16.4 & 28.7 \\
\hline & $\mathrm{CB}$ & 4.096 & 0.25 & 0.08 & 0.07 & 4.5 & 14.6 & 30.8 \\
\hline \multirow[t]{3}{*}{ Mkambarani } & Ap & 6.2 & 1.00 & 0.80 & 0.06 & 8.1 & 15.2 & 53.0 \\
\hline & Bwt1 & 5.789 & 1.40 & 0.18 & 0.24 & 7.6 & 15.2 & 50.1 \\
\hline & Bwt2 & 5.95 & 2.51 & 0.15 & 0.29 & 8.9 & 14.2 & 62.6 \\
\hline
\end{tabular}

Key: Soil profiles: $K Z W-P 1=$ Kiziwa, FUL-P1= Fulwe MKA-P1= Mkambarani: $T E B=$ Total exchangeable bases, $B S=$ Base saturation, $C E C=$ Cation exchange capacity

\subsubsection{Cation exchange capacity (CEC) of the soils}

The CECsoil is medium in the top soil and low in the subsoil. According to [24,12], CEC values of the pedons indicate possible negative influence on the buffering capacity of the soil and reduced retention of base cations by the soils studied. CEC protects soluble cations from leaching out of the plant root zone and helps soils resist changes in $\mathrm{pH}[24,29]$.

3.3.6 Exchangeable sodium (Na) and exchangeable sodium percentage (ESP)

According to $[27,24,30]$, both pedons have low sodium values ranging between $0.15-0.28$ and low ESP values $(<6 \%)$. The low ESP implies that both soils are non-sodic.

\subsection{Mineralogical Composition}

Concentrations of total oxides of elements in soil units studied areas are given in Table 5 . The most abundant oxide determined was $\mathrm{SiO}_{2}$, which ranges from $17-37.4 \%$. The high values of $\mathrm{SiO}_{2}$ indicate the existence of amorphous silica. The $\mathrm{Al}_{2} \mathrm{O}_{3}$ (6 to $\left.10 \%\right), \mathrm{Fe}_{2} \mathrm{O}_{3}(6 \%-10 \%)$ are abundant oxide, probably the soils is derived from gibbsite and hematite [31]. The $\mathrm{SiO}_{2} / \mathrm{Al}_{2} \mathrm{O}_{3}$ ratio ranged from 2.1 to $4.47 \%$ which is generally low according to [27] The same trends of abundance of $\mathrm{Ti}, \mathrm{Si}, \mathrm{Al}$ and $\mathrm{Fe}$ oxides have observed in similar study [31] in soils of Mbeya and soils of Sumar, Philippines. TiO2 was very high for soils of MKA-P1. The concentration of $\mathrm{Fe} 2 \mathrm{O} 3$ in soils indicates the presence of iron oxides particularly goethite.

Table 5. Total elemental composition of selected samples

\begin{tabular}{|c|c|c|c|c|c|c|c|c|c|c|c|}
\hline \multirow[t]{2}{*}{ Profile } & Depth & $\mathrm{Al}_{3} \mathrm{O}_{2}$ & $\mathrm{SiO}_{2}$ & $\mathrm{Fe}_{2} \mathrm{O}_{3}$ & $\mathrm{P}_{2} \mathrm{O}_{5}$ & $\mathrm{CaO}$ & $\mathrm{K}_{2} \mathrm{O}$ & $\mathrm{TiO}_{2}$ & $\mathrm{MnO}$ & Total & \multirow[t]{2}{*}{$\mathrm{ClA}^{\#}$} \\
\hline & (cm) & & & & & $\%$ & & & & & \\
\hline \multirow[t]{3}{*}{ KZW-P1 } & $0-49 / 69$ & 8.97 & 42.42 & 43.2 & 2.45 & 1.19 & 0.49 & 1.56 & 0.12 & 100.4 & 84.22 \\
\hline & $99-132$ & 8.42 & 43.32 & 36.98 & 4.74 & 2.86 & 0.72 & 1.38 & 0.14 & 98.56 & 70.16 \\
\hline & $13-180$ & 6.73 & 44.41 & 39.66 & 4.06 & 1.38 & 0.58 & 1.19 & 0.15 & 98.16 & 77.44 \\
\hline \multirow[t]{3}{*}{ FUL-P1 } & $0-10 / 13$ & 7.29 & 74.35 & 7.78 & 0.00 & 1.81 & 0.99 & 0.44 & 0.001 & 92.66 & 72.24 \\
\hline & $50-95 / 102$ & 9.53 & 69.35 & 11.36 & 0.00 & 0.94 & 0.91 & 0.53 & 0.03 & 99.25 & 83.74 \\
\hline & $168-180$ & 0.00 & 88.64 & 8.34 & 0.00 & 1.07 & 0.81 & 0.37 & 0.02 & 99.25 & 0.00 \\
\hline \multirow[t]{3}{*}{ MKA-P1 } & $0-20 / 32$ & 10.66 & 48.42 & 24.15 & 3.41 & 2.22 & 0.78 & 0.89 & 0.09 & 90.62 & 78.03 \\
\hline & $75-100 / 116$ & 11.21 & 41.33 & 37.93 & 2.98 & 2.12 & 0.34 & 1.15 & 0.12 & 97.18 & 82.00 \\
\hline & $124-175$ & 8.42 & 43.63 & 40.56 & 2.79 & 2.14 & 0.55 & 1.59 & 0.14 & 99.82 & 75.78 \\
\hline
\end{tabular}


Lufega and Msanya; IJPSS, 16(1): 1-12, 2017; Article no.IJPSS.32681

Table 6. Summary of the diagnostic horizons and other features, and classification of the studied soils of Morogoro district, Tanzania (USDA soil taxonomy - soil survey staff, 2006

\begin{tabular}{|c|c|c|c|c|c|c|c|}
\hline \multirow{2}{*}{$\begin{array}{l}\text { Profile } \\
\text { name }\end{array}$} & \multirow{2}{*}{$\begin{array}{l}\text { Diagnostic epipedon(s) } \\
\text { and subsurface } \\
\text { horizon(s) }\end{array}$} & \multirow{2}{*}{$\begin{array}{l}\text { Other diagnostic } \\
\text { features }\end{array}$} & \multicolumn{5}{|c|}{ Soil taxonomy taxa } \\
\hline & & & Order & Suborder & Great group & Subgroup & Family \\
\hline KZW-P1 & $\begin{array}{l}\text { Umbric epipedon; argillic } \\
\text { subsurface horizon }\end{array}$ & $\begin{array}{l}\text { Very deep soil, almost } \\
\text { flat (slope } 0-1 \% \text { ), } \\
\text { clayey particle size } \\
\text { distribution, slighly acid, } \\
\text { ustic SMR, } \\
\text { isohyperthermic STR }\end{array}$ & Ultisols & Ustults & Haplustults & Typic Haplustults & $\begin{array}{l}\text { Very deep, almost flat, } \\
\text { clayey, slighly acid, } \\
\text { ustic, isohyprthermic } \\
\text { Typic Haplustults }\end{array}$ \\
\hline FUL-P1 & $\begin{array}{l}\text { Ochric epipedon; cambic } \\
\text { subsurface horizon }\end{array}$ & $\begin{array}{l}\text { Very deep soil, almost } \\
\text { flat (slope } 0 \text { - } 1 \% \text { ), } \\
\text { loamy particle size } \\
\text { distribution, slightly acid } \\
\text { to neutral, ustic SMR, } \\
\text { isohyperthermic STR }\end{array}$ & Inceptisols & Ustepts & Dystrustepts & $\begin{array}{l}\text { Typic } \\
\text { Dystrustepts }\end{array}$ & $\begin{array}{l}\text { Very deep, almost flat, } \\
\text { loamy, slightly acid to } \\
\text { neutral, ustic, } \\
\text { isohyperthermic Typic } \\
\text { Dystrustepts }\end{array}$ \\
\hline MKA-P1 & $\begin{array}{l}\text { Mollic epipedon; } \\
\text { cambic subsurface horizon }\end{array}$ & $\begin{array}{l}\text { Deep soil, gently } \\
\text { undulating (slope } 5 \% \text { ), } \\
\text { clayey particle size } \\
\text { distribution, slightly acid } \\
\text { to neutral, ustic SMR, } \\
\text { isohyperthermic STR }\end{array}$ & Inceptisols & Ustepts & Dystrustepts & $\begin{array}{l}\text { Humic } \\
\text { Dystrustepts }\end{array}$ & $\begin{array}{l}\text { Deep, gently } \\
\text { undulating, clayey, } \\
\text { slightly acid to neutral, } \\
\text { ustic, isohyperthermic } \\
\text { Humic Dystrustepts }\end{array}$ \\
\hline
\end{tabular}


Table 7. Diagnostic horizons, other features and FAO-WRB soil names for the studied soils of Morogoro district, Tanzania

\begin{tabular}{|c|c|c|c|c|c|}
\hline $\begin{array}{l}\text { Profile } \\
\text { name }\end{array}$ & $\begin{array}{l}\text { Diagnostic } \\
\text { horizon }\end{array}$ & $\begin{array}{l}\text { Reference } \\
\text { soil group } \\
\text { (RSG) }\end{array}$ & $\begin{array}{l}\text { Prefix } \\
\text { qualifiers }\end{array}$ & $\begin{array}{l}\text { Suffix } \\
\text { qualifiers }\end{array}$ & WRB soil name \\
\hline KZW-P1 & $\begin{array}{l}\text { Umbric horizon, } \\
\text { Argillic horizon }\end{array}$ & Alisols & $\begin{array}{l}\text { Cutanic } \\
\text { Umbric }\end{array}$ & $\begin{array}{l}\text { Manganiferric } \\
\text { Clayic } \\
\text { Rhodic }\end{array}$ & $\begin{array}{l}\text { Umbric, Cutanic Alisols } \\
\text { (Manganiferric } \\
\text { Clayic, Rhodic) }\end{array}$ \\
\hline FUL-P1 & Cambic horizon & Cambisols & Haplic & $\begin{array}{l}\text { Ferric } \\
\text { Eutric } \\
\text { Clayic }\end{array}$ & $\begin{array}{l}\text { Haplic Cambisols } \\
\text { (Ferric, Eutric, Clayic) }\end{array}$ \\
\hline MKA-P1 & $\begin{array}{l}\text { Mollic horizon, } \\
\text { Cambic horizon }\end{array}$ & Cambisols & Haplic & Dystric & $\begin{array}{l}\text { Haplic Cambisols } \\
\text { (Dystric) }\end{array}$ \\
\hline
\end{tabular}

Lead and arsenic was almost not detected in all soils studied. Generally, high levels of $\mathrm{SiO} 2$ in the studied soils as compared to $\mathrm{Al} 2 \mathrm{O} 3$ and Fe2O3 are probably due to amorphous silica and quartz [13].

\subsubsection{Chemical index of alteration (CIA)}

The overall CIA values for KZW-P1 varies from 70 to $84.22,83.74$ to 72.24 for FUL-P1 and 75.78 to 82 percent for MKA-P1 Table 5. Nevertheless, there is no strong variation of the CIA values across and within the pedons except in FUL-P1, at a depth of 168 - 180 subsoil, where a CIA value of 0 was recorded which indicates no weathering process happening. According to classification of weathering intensity by [13], Samples from these soil units constitute strong weathering while few of them fall in the intermediate stage. Results revels that there is strongest weathering in Kiziwa and Mkambarani, except one layer in Fulwe. According to [7], soils having $\mathrm{CIA}$ values for average shales range from 70 to $75 \%$, and the large amount of aluminous clay minerals (such as kaolinite) formed during intensive chemical weathering is reflected in the high CIA values (80-100) of muds formed under tropical conditions. The studied soils probably contain shales and kaolinite because of high CIA values.

\subsection{Soil Classification}

Soil morphological, physical and chemical properties enabled definition of the diagnostic horizons and other features that assist to classify the soils. Table 6 presents a summary of the diagnostic horizons and features for classifying the soils up to the family level of the Soil Taxonomy (Soil Survey Staff, 2006) and up to
Tier-2 of the FAO World Reference Base. Similarly, Table 7 presents diagnostic horizons and features for classifying soils according to [11].

\section{CONCLUSION}

The following conclusions can be made from the results of the study;

a. Soil physico-chemical characteristics differed from one pedon to the other under similar agro-ecological conditions.

b. Soil physical properties had an influence on the available water content, soil strength and matric potential of which have influence on nutrient uptake and root ramification.

c. Soil pH in both sites is slightly acidic with low to very low exchangeable cations that could have implications on the CEC, nutrient uptake and consequently nutrient imbalances and induced toxicities.

d. Both soils are weathered with KZW-P1 and MKA-P1 profile showing more advanced stages of weathering thus, necessitating immediate attention to revert the already depleted plant required nutrients.

\section{ACKNOWLEDGEMENTS}

We wish to acknowledge Alliance for Green Revolution in Africa (AGRA) through SUA-AGRA Soil Health Program for funding this work.

\section{COMPETING INTERESTS}

Authors have declared that no competing interests exist. 


\section{REFERENCES}

1. Msanya BM, Kimaro DN, Kimbi GG, Kileo $E P$, Mbogoni JDJ. Land resource inventory and suitability assessment for the major use types in Morogoro urban district, Tanzania. Soil and Land Resources of Morogoro Rural and Urban Districts, Volume Department of Soil Science, Sokoine University of Agriculture, Morogoro Tanzania. ISBN. 2001;605:29.

2. Msanya BM, Kaaya AK, Araki S, Otsuka H, Nyadzi Gl. Pedological characteristics, general fertility and classification of some benchmark soils of Morogoro district, Tanzania. African Journal of Science and Technology (AJST) Science and Engineering Series. 2003;4(2):101-112.

3. Hagan D, Dobb C, Timilsina N, Escobedo F, Toor G, Andreu M. Anthropogenic effects on the physical and chemical properties of subtropical urban soils. Soil Use and Management. 2010;28:78-88.

4. Obura PA. Effects of soil properties on bioavailability of aluminium and phosphorus in selected Kenyan and Brazilian soils. Ph.D Thesis, Purdue University, USA. 2008;12-15.

5. Jaedzold R, Schmidt $H$, Hornetz B, Shisanya $C$. Natural conditions and farm management information. $2^{\text {nd }}$ Ed. Part A: West Kenya. Sub Part Al Western Province. 2007;319.

6. Ngome AF, Mtei MK, Becker M. Leguminous cover crops differentially affect yields in Western Kenya. J. Agric. Rural Dev. Trop. 2011b;112:1-10.

7. Soil Survey Staff. Keys to soil taxonomy. $11^{\text {th }}$ Edition. United States Department of Agriculture. NRCS, Washington DC. 2006;346.

8. IUSS Working Group WRB. World reference base for soil resources 2006, first update 2007. World Soil Resources Reports No. 103, FAO, Rome; 2007.

9. Harrold ML. Field experience on light soils, Soil physical conditions and crop production. MAFF Technical Bulletin no. 29, HMSO, London. 1975;22-51.

10. Msanya BM, Kimaro DN, Kimbi GG, Kileo $E P$, Mbogoni JD. Land resources inventory and suitability assessment for the major land use types in Morogoro Urban District, Tanzania. In: Soils and land resources of Morogoro Urban District, Tanzania. Department of Soil Science, Faculty of
Agriculture, Sokoine University of Agriculture, Morogoro, Tanzania. 2001;4. ISBN: 998760529 X.

11. FAO. Guidelines for soil description. $4^{\text {th }}$ edition. Food and Agriculture Organization of the United Nations. Rome. 2006;66.

12. Munsell Color Company. Revised Edition. Munsell soil color charts. Macbeth Division of Kollmorgen Instruments Corporation, New York; 1994.

13. Blake GR, Hartge KH. Bulk density. In: Methods of soil analysis, Part 1 Physical and mineralogical methods. (Edited by Klute A.). American Society of Agronomy. Madison, Wisconsin. 1986;364-374.

14. Baize D. Soil science analysis. A guide to correct use. John Wiley and Sons Ltd. West Sussex. 1993;192.

15. Day PR. Particle fractionation and particle size analysis. In: Black CA, Evans DD, White JL, Ensminger LE, F.E. Clark FE (Eds.), Methods of Soil Analysis: Physical and Mineralogical Methods, American Society of Agronomy, Madison, Wisconsin. 1965;545-566.

16. USDA. Soil taxonomy. A basic system of soil classification for making and interpreting soil surveys. Agric. Handbook no. 436. Washington D.C; 1975.

17. Okalebo JR, Gathua KW, Woomer PL. Laboratory methods of soil and plant analysis: A working manual. 2nd Edition. 2002;128.

18. Mehlich A. Mehlich-3 soil test extractant. A modification of Mehlich -2 extractant. Commun. Soil Sci. Plant Anal. 1984;15(12):1409-1416.

19. Murphy J, Riley JP. Modified single solution method for determination of phosphate in natural waters. Analytica Chemica Acta. 1962;27:31-36.

20. Nelson DW, Sommers LE. Total carbon, organic carbon and organic matter. Methods of soil analysis, Part 2; Chemical and mineralogical properties, 2nd edition. (Edited by Page AL, Miller RH and Keeney DR). American Society of Agronomy, Madison, Wisconsin. 1982;539-579.

21. Bremner JM, Mulvaney CS. Total nitrogen. In: Methods of soil analysis, Part; Chemical and mineralogical properties, 2nd edition. (Edited by Page AL, Miller RH and Keeney DR). American Society of Agronomy, Madison, Wisconsin. 1982;595-624.

22. Chapman HD. Cation exchange capacity. In: Methods of soil analysis (Black C. A. 
Ed). Am. Inst. Agronomy, Madison, Wisconsin. 1965;9:891-901.

23. Lal R, Shukla MK. Principles of soil physics. Marcel Dekker, Inc. New York. 2005;699.

24. Aticho A. Evaluating organic carbon storage capacity of forest soil: Case study in Kafa zone Bita district, Southwestern Ethiopia. American Eurasian Journal Agriculture Environmental Science. 2013;13(1):95-100.

25. Euroconsult. Agriculture compendium for rural development in the tropics and subtropics. 3rd Revised Edition. Elsevier, Amsterdam. Oxford. New York. Tokyo. 1989;740.

26. Adamchuk VI, Mulliken J. Precision agriculture site-specific of soil pH (FAQ), extension paper 713 , historical materials from University of Nebraska-Lincoln. 2005;EC05-705.
27. Brady NC, Weil RR. The nature and properties of soils. 14th Edition. Pearson Education, Inc. 2008;90-99.

28. Nesbitt HW, Young GM. Early proterozoic climate and plate motion inferred from major element chemistry of lutites. Nature. 1989;299:715-717.

29. Msanya BM, Otsuka H, Araki S, Fujitake N. Characterization of volcanic ash soils in South-Western Tanzania: Morphology, physiochemical properties and classification. African Study Monographs, Suppl. 2007;34:39-55.

30. Van Wambeke. Criteria for classifying tropical soils by age. Journal of Soil Science. 1991;13(1):124-132.

31. Kileo EP. Land suitability assessment of the Wami plains in Morogoro, Tanzania with respect to the production of the main food crops and extensive grazing. MSc. Thesis, Sokoine University of Agriculture, Morogoro, Tanzania. 2000;152.

(C) 2017 Lufega and Msanya; This is an Open Access article distributed under the terms of the Creative Commons Attribution License (http://creativecommons.org/licenses/by/4.0), which permits unrestricted use, distribution, and reproduction in any medium, provided the original work is properly cited.

Peer-review history:

The peer review history for this paper can be accessed here: http://sciencedomain.org/review-history/19020 